\title{
A Condensation Effort: Pina, Lacan, and a Matter of Writing
}

\author{
Marcus André Vieira* (1) \& Thereza De Felice (1) \\ Pontifícia Universidade Católica do Rio de Janeiro, Rio de Janeiro, RJ, Brazil
}

\begin{abstract}
The present article intends to articulate the notion of letter as littoral, as forged by Jacques Lacan in his text Lituraterre, with the German artist and coreographer Pina Bausch's dances and plays. We go from the signifier to the letter in Lacan's teachings and proceed with an analysis of the creative process of Pina Bausch's works, aiming to that which seems to present itself as having no sense, as something out of language's reach; out of what one can say and tell within a field of multiple meanings. Thus, we intend to sew those psychoanalytic concepts to the fragments appearing in Bausch's productions in order to achieve a further grasping and understanding of the concept of letter in Lacan.
\end{abstract}

KEYWORDS: Jacques Lacan, Pina Bausch, letter, littoral, gestures

\section{Um Esforço de Condansação: Pina, Lacan e uma Questão de Escrita}

\begin{abstract}
RESUMO - A proposta deste artigo é aproximar a noção de letra como litoral, tal como forjada por Jacques Lacan em seu texto Lituraterra (1971/2003), das danças/montagens da artista e coreógrafa alemã, Pina Bausch. Para tal, constrói-se um percurso do significante à letra no ensino de Lacan, bem como uma análise do processo criativo das montagens de Pina, visando ao que parece se apresentar ali como fora de sentido; fora do que a linguagem pode recobrir, do que se pode dizer e produzir significações. Assim, pretende-se fazer uma costura entre os referidos conceitos psicanalíticos e os fragmentos que se apresentam nas produções bauschianas, a fim de encontrar um recurso possível de transmissão sobre a letra.
\end{abstract}

PALAVRAS-CHAVE: Jacques Lacan, Pina Bausch, letra, litoral, gestos

\section{INTRODUCTION}

This article starts from the hypothesis that we could find in the works of German artist and choreographer Pina Bausch and in the way gestures are articulated in her pieces compositions which result from a specific creative process, a dimension of out-of-sense that presents itself in that creative experience and seems to resonate with something psychoanalysis tries to grasp. Such dimension appears as the linearity of a narrative that is not predominant in her works, unlike, for instance, in classical ballet pieces in which well-assembled and composed sense and meaning seem to be the guiding threads.

The dimension of an out-of-sense, in psychoanalysis, with Jacques Lacan, leads us to that which, in the encounter of a body with language, is not overlapped by it, by the symbolic, by the signifier; that is, to that which lies within the outer limits of language, an indication of what Lacan called the real. This theme permeates all of his teaching, but what interest us in order to formalize our hypothesis is one of the ways he found to speak of this real register - inaccessible in any other way, but from the symbolic -, the notion of letter. The letter shall help us to think the non-sense dimension in Pina's works, but, more than that, our wager is that her assembled pieces shall serve us as a good resource for the study of this concept.

Yet, another choice shall be made. The letter appears in several ways in Lacan's teaching; it can be understood as the signifier itself, as the object $a$ or, as it appears at the end of his teaching, as littoral. We choose this third aspect, as it appears in the text Lituraterre, in 1971, understanding that in it, using Japanese calligraphy, Lacan forges a concept

*E-mail:marcus@litura.com.br

- Submetido: 10/06/2017; Revisado: 10/12//2018; Aceito: 02/11/2019. 
that refers to a borderline space between knowledge and jouissance. In other words, he introduces us to the littoral as a space in which something of the real is grasped, without, notwithstanding, becoming a signifier, but in a material way, no longer unapprehensible or ineffable. The letter appears as a concept difficult to grasp and yet no less essential for sustaining what has been consolidated as the Lacanian praxis. Thus, we believe it is relevant to try to articulate yet another resort that serves to transmit the notion of letter, following Lacan's steps in calligraphy, waging on an encounter with literalness and materiality in the steps of Pina Bausch.

In calligraphy, we see, there is a gesture that counts. There is a singularity apprehended in its materiality. The calligrapher's gesture writes a letter that comprises a dimension unfit for communication and, yet, is printed. Without dispensing the signifier, since nothing can be said outside the signifying order, an effect of real is realized on the littoral. This is the littoral-letter effect.

It is this letter effect, that we suppose, one can find in Pina Bausch's compositions with gestures. Her creative process seems to illustrate this in a way that teaches us something concerning the Lacanian theory. She collected gestures and words from her dancers, from the cities in which they performed, from culture, and made a cutout with which she assembled a piece of superimposed fragments, glued together; more a seam or do-it-yourself composition than a well-connected story. These fragments were transformed into plays in a process she called a reduction operation.

This reduction operation is also the name used by Jacques-Alain Miller in The Bone of an Analysis (1998/2015) to forge a concept that describes the operation that occurs in the course of an analysis. We shall not forcefully overlap the two operations, but we shall extract points of contact that exist between them that seem to support the approximation we are making between the letter and that which was produced by Pina's operation. In the analysis, we are faced with a reduction in the series of repeated signifiers, so that, at the end of that transfer relation, something unprecedented can be produced which, like the calligraphic letter, doesn't communicate anything, but is printed in that littoral zone, something we examine in this article. The neologism, for example, can be a form in which an invention appears at the end of this analytical operation-reduction. A word-invention, outside the series, but also inside, since it operates the game of signifiers.
Pina's assembled pieces also refer us to this neologism effect as a result of the reduction in question. We shall see that it does not dispense the signifying articulation; as we said, nothing concerning the real can be said but through the lens of the symbolic. Therefore, meanings also appear in this game, but with a much more provisional than predominant character, as they do, for example, in classical ballet pieces. That is how we suppose that is possible to visualize in her pieces the three levels - signifier, meaning and letter -, the third being what we intend to privilege in this article.

We take the work of this artist as a structure, not as content, following the orientation given by Lacan's reading of Hamlet, in the seminar Desire and its interpretation (1958-1959). The psychoanalyst is to be interested in the "structure value" of a work, taking it as a "mode of discourse":

That the way a work touches us, precisely in the most profound fashion, namely on the unconscious, is something which has to do with an arrangement, a composition (...). I mean that we are not dealing, either, contrary to what is thought, with the poet's unconsciousness, even if it bears witness to its presence through some unintentional aspects of his work, by parapraxes, by symbolic elements not realized by him. This does not interest us in a major way. A work's value comes from its organization, through the fact that it establishes superimposed planes within which the proper dimension of human subjectivity can find its place. (Lancan, 1958/2008, p. 295 e 296. Free translation).

This precisely points in the delimitation of the field that serves us in the research - namely, the field of gestures, movements, fragments, presented by Pina in superimposed plans, as referred by Lacan in the passage above. This is what shall allow us to seek resonances with the letter.

Thus, in order to establish our hypothesis, we shall examine the path undertook by Lacan from the signifying order to the letter. We weave a seam between two fields dance and psychoanalysis -, based on the perspectives of an author and a choreographer who launched themselves into this out-of-meaning and who seem to have found a concreteness for it, which allows us to articulate a way to speak of it. It is also important to emphasize that the reading to be made of Pina Bausch's work is just one way of doing it, one among so many possible others, according to this researcher's bias. Our direction in this article, therefore, is not reading Pina from a psychoanalytical point of view, but asking: what can Pina teach us concerning the letter?

\section{PINA}

Philippine Bausch, or Pina Bausch, as she came to be known, was a German choreographer renowned for the pieces she presented with her company, the Tanztheatre Wuppertal. She was born in 1940, in the city of Solingen, in Germany. According to her account in a speech given in 2007 entitled "What moves me", it was in the music, in the speech and in a going-in-and-out environment that, in her parents' restaurant, the first experiences with dance appeared. All of this, she says, was taken to the stage, along with the unspeakable danger of the war that terrified those 
times. At the age of fourteen, she started to follow Kurt Jooss, creator of dance-theater who, inspired by Rudolf Von Laban, tried to liberate dance from the standards of classical ballet. She began her training in Germany where, after a long trajectory - with experiences in Julliard, New York, alongside the greatest names of modern dance -, in 1973, she was invited to direct the dance company of the Wuppertal Opera, soon to be, under her direction, the Tanztheater Wuppertal, in reference to the origins of Laban and Jooss (Cypriano, 2005). Amidst strong resistance on the part of the dancers and spectators to which in Pina's creations seemed subversive, between horror and a sense of humor, something emerged there of a brilliant invention. Her method was based on loose words, collected from the world and from her dancers, intertwined by the choreographed movement that did not form a gestalt, a good form, as it is expected in classical ballet. In the creative process of a piece, Pina asked questions to her dancers and the answers were her material. In an interview with Christopher Bowen, Pina says:

Usually I ask a question and they think about it, and when they are ready, then they show it. But they practice what they show, and everyone is asked to write what they have done. We collect all the material, and sometimes after weeks, I ask, "can you do that? Show me again". (Climenhaga, 2013, p. 100).

We see that, based on unique and singular elements, she produced a choreography that repeated and reproduced itself. It is not, therefore, a matter of improvisation or a supposed "free" dance. Pina seemed to know that there is a narrative assembly that she cannot forgo, which makes it possible for accurate pieces to happen, with markings, time, music, etc. It is, however, the way the word clippings appear, in gestures and movements - that is, this assembly -, that interests us here. Even if meaning productions are possible, the strongest aspect of her pieces seems to be a certain style of discourse, a "non-linearity". They are fragments, often glued or overlapped, more than articulable.

This is what Anne Cattaneo says about a controversial version Pina Bausch made of Shakespeare's Macbeth :

Rather than presenting a production of Macbeth, Bausch organized her performance around fragments of text from the play, presenting images of female manipulation and male power and helplessness. The performance was disrupted and had to be stopped after the first half hour (Cattaneo, 1984/2013; p. 82).

Cattaneo shows us, in this example, that this structure of fragments promotes an encounter with an opacity that shakes, to a certain extent, a more or less stable knowledge - in this case, the previous literary knowledge concerning the referred Shakespeare play. The content of the images - female manipulation, male power and helplessness - is the inevitable message that the piece carries. It is its body, however, in its materiality - fragments of text - thatseems to be Pina Bausch's strong mark.
In her relationship with the dancers, the way she established a space for invention, Pina seemed to know that there is an unknown knowledge - this is how Lacan defines the unconscious in his Seminar 20, Encore (1972-73) -, that marks the body, the bones, the movements: a certain way for the foot to step on the ground, the hand to reach the object, the mouth to move while speaking. Marks that are not exactly representable behaviors. In order to achieve that, she says, a language must be found:

It is necessary to find a language with words, with images, movements, moods, that makes us perceive something that is always present. This is a rather precise knowledge. (...), a precise knowledge that we all have, and dance, music, etc. they are a very precise language with which this knowledge can be perceived. It is not about art, nor about mere talent. It is about life and, therefore, finding a language for life. And, as always, it is about that which is not yet art, but what could perhaps become art. (Bausch, 2000, p. 11).

We can read in this passage that there is a possible place in art for the writing of this unknown mark, in a knowledge sense, but that can be "perceived" in Pina's words. This place may be what Lacan defines as littoral.

Bauschian creations face us with a body that seems to be closer to Freud's driven body than to the useful biological body that serves to organic functions. This is because this unknown knowledge is written on the body, as we will see, on the driven body, that is, a body marked by jouissance. Let us remember the play Müller Café (1978), in which, in one of the emblematic scenes, a couple tries to fit together their bodies, when a third person comes to dismantle them, following what they try to reassemble and so on and so forth. Instead of taking the scene by the countless meanings that we could produce, let us think about the pure repetition that takes place in it. Movements and gestures are repeated so many times that, in a span of time, any possible meaning is emptied, in such a way that the impossible of this scene is almost the only thing that remains. Meanings are temporary, that is what Pina shows us, and what's left of this is where we want to go with her.

Cattaneo tells us that this is a "reduction operation", citing something Pina said during a rehearsal: "To reduce without diminishing. Language too. Many of the words and sentences have become superfluous. Images appear in their place" (1984/2013; p. 86.).

In "The bone of an analysis" (1998/2015), Jacques-Alain Miller proposes a new concept concerning the trajectory of an analysis which he, precisely, calls "reduction-operation". Without pretending to make it an equivalent of the reduction operation involved in Pina's creative process, it seems to us that this coincidence in the naming of these operations can help in the articulation we aim at in the present work. The concept of operation-reduction proposed by Miller is a successful attempt to account for what is articulated in an analysis "between the signifier aspect and the aspect of 
jouissance" (1998/2015, p. 10). He describes the possible transition that takes place in the analytical operation concerning knowledge. A reduction that implies a transition from the signifier to the jouissance, to "knowing how to deal" $(1998 / 2015$, p.12). We will return to this concept at the end of the present work, as it shall become clearer once we address, in Lacan, the theory of signifiers and the letter.
So far, we have an assembly that results from a reduction, and that counts on bodies, on the drive side and, therefore, an assembly of words and images. In this, we suppose there is also a dimension thatwe shall be able to touch with the concept of letter. We shall then build a trajectory in Lacan, from the signifier to the letter, to reflect on this dimension concerning what Pina's pieces can teach us.

\section{SIGNIFIER AND SIGNIFIED}

The Freudian invention of a speech setting and the theory of dreams are the fundamental premise on which the Lacanian theory of signifiers is based. Speech is the tool available to the psychoanalyst, through which he receives from the patient "his frame, his material and even the background noise of his uncertainties" (Lacan, 1957, p. 497), and should be taken as a text. Lacan approaches this text throughout his teaching using the signifier - signified pair, but, also, using a third way that, for now shall only be pointed to its existence, which brings us to the plane of singularity, the letter's plane.

The plane of meanings, representations was widely explored by Freud and located in relation to consciousness and the unconscious. Even so, this plane no longer could account, in the Freudian theory, for everything that appeared in theoretical-clinical investigations.

Freudian texts always reveal points that escape elaborations of meaning and appear in the experience of analysis. The navel of the dream, for example, left open, for Freud, an unrepresentable, an unfathomable point of exhaustion of meaning (Freud, 1900). However, meanings, fictions, are the only means we have to grasp something of that unfathomable which is not found "beyond discourse", but in words themselves (Lacan, 1953, p. 255). Thus, we do not give up on meaning, but since we do not find ourselves attached to it, we can come to build a way, perhaps a style, resting on the edge of this meaninglessness. Meanings, then, belong to the imaginary order. Signifiers, as taken and modified by Lacan from the theory of linguist Ferdinand de Saussure, shall be the symbolic markings of these meanings; points of gravity that organize the order of meanings in an articulated chain of signifiers.

In 1960, Lacan says that, in the entry operation of the being of language, the Other - which could be understood as culture, the symbolic field that orders the world, or language itself - is the "previous place of the pure subject of the signifier" (Lacan, 1960, p 821. Free translation). It is the sayings of the Other that constitutes a possible field of existence in language, in the order of signifiers. "The first saying states, legitimizes, sentences, it is an oracle, it gives the other real its obscure authority" (Lacan, 1960, p. 822, Free translation). That concise saying which is neither content nor attribute, constitutes that which Lacan called the unary trait (1960, p. 822). The being is already born immersed in the signifiers of the previous Other, since one is spoken by the Other even before his birth. It is from this bath of signifiers that a trait is made which, in turn, guides the way that being will settle in with the world, with these signifiers that precede him. We shall later see that this trait makes for an erogenous body, constituted in the dimension of jouissance and desire.

The constitution of a body as a unit, then, can only happen through the Other that precedes it. According to the Lacanian theory of The Mirror Stage (1949), the being immersed in language sees in the mirror something that does not exist without the Other. The self-unity is constituted from an assumption of certainty, always linked to what remains as an essential question: what does the Other, who looks at me, want from me? This, in any case, shall always be a question with no corresponding answer.

This is paradigmatic of the non-correspondence between signifier and signified in the constitution of the body; the signifier is ambiguous. The Other, or the signifier of the Other, does not respond symmetrically to the self-unity formed in the mirror. Thus, a hole always persists. The body is constituted in the ambiguity of the signifier, hole, and in the image that fixes itself in the mirror and forms the ideal self, hooked to all the meanings that the self will produce (Lacan, 1960, p. 823).

We then have a signifier as a hole and a signified as an image, constituting a body. The third element, the letter, we shall see, is that without which a body cannot be sustained. Articulated to the other two elements, it is borderline, a border, or littoral; it makes it impossible to do anything other than the possibilities delimited by the game between the consistency of the image, the hole in the signifier, and the singularity of the letter. 


\section{SIGNIFIERSTHEORY}

It is worth examining a little more deeply the notions of signifier and signified previously introduced. What does Lacan teach us about the signifier and the signified, as forged from Saussure's theory? For the linguist, the signifier is placed over the signified, with a bar between them that resists signification (Lacan, 1957, p. 500). Michel Arrivé locates that which, for him, would be the main divergence between Saussure and Lacan:

In Saussure, there is, fundamentally, a theory of the sign; the theory of the signifier is part of this theory of the sign: without a sign, there is no signifier (nor meaning). In Lacan, things are quite different. There is, marginally, a theory of the sign. But it does not articulate with the theory of the signifier: signifier (and signified) on the one hand, sign on the other are disjoint. (Arrivé, 1986/2001, p. 98. Free translation).

The Saussurean sign makes a unity between signifier and signified, as if there were a correspondent for the other. Arrivé also comments the point where Lacan breaks with Saussure:

(...) the ellipse that encloses Saussurean schemes has disappeared, as well as the two arrows of opposite meanings whose function, in Saussure, is to figure out the reciprocal presupposition relation between the two terms. The elision of these two elements of the scheme must be put with the sliding of the meaning over the signifier, if the meaning is closed with the signifier inside a cell, (...) it cannot "slide". (Arrivé, 2001, p. 106. free translation).

This is how Lacan distances himself from Saussure, eliminating any possible unity between signifier and signified, and extracts what is at the heart of his theories concerning the relations between the two:

(...) that no meaning can be sustained except by referring to another meaning: which ultimately touches on the observation that there is no existing language to which the question of its insufficiency is posed to cover the field of meaning, since meeting all needs is an effect of its existence as a language. (Lacan, 1957, p. 501. Free translation).

The signifier, therefore, cannot represent a single meaning only. The slides of meanings necessarily refer to the signifier's slides. This impossible univocity - that is, the possibility of misunderstanding that characterizes human spoken languages - is the path that can lead us to bet on an order of non-sense in discourse, no matter how many slides of meaning it entails. Such wage is very dear to Lacanian psychoanalysis, because, with it, the pillars of a practice that can distance itself from a clinic of infinite meanings are put in place.
Thus, in the way Lacan takes Saussurean theory, the signifier is that which gives rise to meaning, although there is no correspondence between the two (1957, p. 503).

In the constitution of language, signifiers are articulated in chains or networks, since one always refers to the other. It is from this articulation that meanings will occur. Thus, the slide of meanings over signifiers will be constituted, tied by what Lacan called upholstery buttons (Lacan, 1957, p. 506) ${ }^{1}$.

All this points to the revelation that Lacan underlines: the being in language uses common language to express something that, in any case, will be completely different from what his neighbor expresses (1957, p. 508). This is because, anyways, the closed order in which the signifiers are articulated for someone will be founded on a unique and singular mark - perhaps the letter -, according to the way that being of speech will appropriate the Other and constitute a singular and insurmountable way of reading the world.

Lacan goes back to Freud's "The Interpretation of Dreams" (1900), to situate what, in his reading, points to the signifier's value of images, and not to the meaning. When Freud speaks of the "verbal ambiguity" in the dream (Freud, 1900, p. 670), he shows that a word that appears in the dreamer's associations serves in different ways, in various branches of the associative chain. One word knots the slides of associations, beyond one meaning. In this direction that Freud puts us, the psychoanalyst can distance himself from deciphering, which is linked to the imaginary and is of no use to the real, except for masking it.

Lacan takes the dream work as a counterpart to the function of discourse, being only different ways the real has of presenting itself. The articulations at stake, he tells us, are essentially a matter of writing, and follow the laws of the signifier (1957, p. 515). That is how Lacan understands that Freud privileged the signifier, even though he did not have the linguistic resources that would allow him to follow in this direction (1957, p. 517).

Thus, for Lacan, it is a question of analyzing the text and not the content, the imaginary. For the imaginary, we have the self, a decoy (Lacan, 1957, p. 524). Now, if the self is not the master of its own house, "then who is this other to whom I am more attached than to myself, since at the heart of my assent to my own identity, it is still him who wags me?" (Lacan, 1957, p. 528. Free translation). It is something that cannot be achieved through knowledge, but which vibrates the body of the speaking being (1957, p. 531).

1 We shall not explicit, in this article, the Lacanian theory about the Name-of-the-Father, in which Lacan uses such an expression, points-ofenough. In the pursuit of the research, however, we shall have space to do so. 


\section{THE LETTER}

What letter are we talking about in this text, in this body, written outside the field of knowledge? In "The instance of the letter in the unconscious or reason since Freud" (1957), Lacan approaches the concept of the letter in such a way that, at times, we understand that it coincides with the signifier. The Lacanian maxim that the unconscious is structured as a language appears in this text pointing to the letter as the indicator of this structure of the unconscious. However, that is not the dimension of the letter we aim to reach. From this text, we will extract the two directions on the letter it provides us, at first: it must be taken "literally" and it is a "material support" (Lacan, 1957, p. 498. Free translation) of the signifier.

We have seen that we put ourselves in the path of the letter if we place the signifier articulations as a question of writing. The letter plane is, therefore, a material, literal plane, it is not ineffable. We will see that the letter is a way that Lacan found to apprehend singularity, or a way to hook the real'.

Our choice of bias on the letter in Lacan's teaching is the one he presents us in his text Lituraterre (1971), the letter as littoral. In this text, Lacan tells us of his experience aboard an airplane that flew over the Siberian plains, where some watercourses were formed, only seen at a given moment when sunlight reflected them. This image serves to situate the letter as a boundary space between territories, between knowledge and jouissance. The letter as the presence of the real, written on the body (Lacan, 1971, p. 19).

The fact that there is a spoken and speaking being inserts him in a language that is constituted of what the being uniquely appropriates from spoken language, and the letter is the carrier, so to speak, of this singularity, at the material level of writing that takes place on the body which vibrates him; "The letter is inhabited by him who speaks" (LACAN, 1971, p. 19. Free translation). We can only read the nominations that come from the Other through a special way of reading the world, inscribed by the letter, which goes back to the pieces that make up the unary trait on the body. It is in writing as "an artifact that inhabits language" (Lacan, 1971, p. 23. Free translation) that we speak of a letter as something precipitated from the encounter of the body with the spoken language.

We find in the text Taking the body literally or how to talk about the body? (1977), by Serge Leclaire, some clarifications concerning the letter. The erogenous body, he tells us, is only insofar as it is ordered in a dimension of jouissance (1977, p. 54), which is only established from

2 Lacan also found other ways to do this, among which, the sinthome - Seminar 23, The sinthome (1975-76) - and object $a$ - Seminar 10 The Anguish (1962-63) -, but here we shall stick to the investigations concerning the letter. the unity that comes from the Other. "The terms mark, fixation, are necessarily used to describe the establishment and, above all, the almost indelible persistence of erogeneity in a point of the body" (Leclaire, 1977, p. 59). And what is unique concerning the way a body makes itself erogenous? The author tells us that it is, precisely, the entrance of jouissance. In the gap between the call to the Other and partial satisfaction, the dimension of jouissance takes place, which uniquely fixes a part of the body as an erogenous source; a "crater of jouissance" opens (Leclaire, 1977, p. 60. Free translation) where a letter is inscribed.

According to the author, then, as we can see, the letter is something that captures the jouissance. The effect is the production of a singular way of jouissance, a living movement around that singularity, that jouissance written on the body by a letter.

(...) The physical body, in its surface and density, is offered or resists, but, in any case, supports the erogenous inscriptionincision in the same way that a book's page supports and makes appear - in a sense, constitutes - the letter inscribed in it (Leclaire, 1977, p. 63. Free translation).

This text serves to emphasize that, first, the letter concerns a type of writing and, also, that the letter has to do with the body in its dimension of jouissance.

Regarding that what makes a body a body of jouissance, that is, a living body, and the implications of this in an analysis - more precisely, for the end of an analysis, as we shall later see -, we now return to Jacques-Alain Miller, The Bone of An Analysis (1998/2015), which will also bring us back to the operations that we are trying to understand, in psychoanalysis and in Pina Bausch's, with the letter.

The bone of an analysis is how Miller names in this text what we repeatedly find, almost always in the same place, and tends to become evident when we submit to the analytical setting. In its metaphor, it's Carlos Drummond de Andrade's stone in the middle of the road. There is always a stone in the middle of the road, whose position in an analysis is not that of an obstacle to be overcome, but more than a bone, which does not yield, to be sculpted. The reduction operation is that at stake in this artisanal work, Miller proposes (1998/2015, p. 32).

And what exactly does this operation reduce? For it to occur, it is necessary, first, to listen to the repetitions in the discourse that the patient brings $(2015$, p. 36$)$. It is in repetition that a constant can be found, a series of signifiers that begin to circumvent the same point, equivocating their meaning and, thus, reducing them. "The treatment seems, with effect, to make the subject's enunciations converge to one essential's enunciation" (2015, p. 36 and 37. Free translation). 
These first two moments of reduction - repetition and convergence to one or a few enunciations - are, ultimately, the encounter with the fact that the body is an "effect of the signifying mark" (2015, p. 37 . Free translation). There is also a third moment, which is the encounter with "the bone of this signifying machine, the impossible residue of the repetition functioning" (1998/2015, p. 52. Free translation). What always escapes the signifying articulation, which emerges from the symbolic reduction and does not fit in the enunciations being lapidated during the analysis, refers us to the contingency plan, Miller says. We shall not dwell here on what Lacan says of contingency in relation to what is impossible, possible and necessary, in his Seminar 19 (1971-1972). For now, it is enough that we understand what Miller wants to tell us when he introduces us to this plan:

It means that when we ask ourselves why such term has such value in a subject's psyche, we are always referred to contingency, to the contingency of a particular history, precisely to something that, in Lacan's time, ceases to not be written. From the moment we ask ourselves why that signifier has a fundamental value for that subject, and we cannot deduce, we are then faced with a contingency, that is, we are before something that was found and that could have been otherwise, although in that level it could only be so (Miller, 1998/2015, p. 55. Free translation):

It is the contingent encounter of the body with the signifier that produces a way of jouissance, and it is the encounter with that particular mode of jouissance that an analysis can promote. In short, in the analytical operation, speech as a tool is the almost palpable experience that presents meanings are reducible to signifiers, in such a way that, if taken to its ultimate consequences, it is the body marked by the signifier, or the body in the dimension of jouissance, on the contingency plane, that someone will have to face at the end of an analysis.

We have, then, the body of jouissance, which only exists in the articulation with the signifier, and that refers to the contingency of that articulation, the rest. This is where something is added to the reduction, because otherwise we could easily fall into relativism and conclude that, then, an analysis is a process of purely assuming that there is an irreducible remainder, an exercise in conformity. The operation of an analysis is, however, a work that carves something, as Miller says, that produces or, better, that leads to an assembly, the result of reduction.

What does not yield is the symptom; "the signifier, as such, refers to the body, and this reference is made under the symptom modality" (Miller, 1998/2015, p.85. Free translation). The symptom is produced by the fact that the signifier affects the body as jouissance, and it is the symptom itself, the bone of an analysis (Miller, 1998/2015, p. 90). The end of the analytical operation, then,
(...) means that the symptom, we have to live with, that we must, as we say in French, faire avec, that is, that we must deal with. Saying that one comes to identify oneself with the symptom means that I am as I experience jouissance. (Miller, 1998/2015, p. 90. Free translation)

How can we draw consequences from this for our letter theme and, even more, for what we suppose to appear from this in Pina Bausch? This plane of analytical reduction that Miller addresses through the symptom is the plane of reduction to the real $(1998 / 2015$, p. 53), and we think that this is also the case for reduction implied in the presentation of the littoral. Being the end of an analysis, according to Miller, an assembly work with which remains, a work that goes from the signifier to the jouissance, and studying the Bauschian creative process and its own reduction-operation, can we speak of a "faire avec" the letter in Pina's assembly pieces? Inversely and, more precisely: can we say that Pina's assembly pieces teach us about a "faire avec" the letter? The letter brings to the material plane, the plane of writing, the singularity that is at stake in this artifice of this "faire avec", in the lapidation of the bone.

Éric Laurent, in his text The stolen letter and the flight over the letter (2010), analyzes writing in Lituraterre (Lacan, 1971) and helps us understand what Lacan writing was dealing with. He goes from what the letter would represent in the Seminar on the purloined letter (1957) to the letter in Lituraterre. In the first text, Lacan analyzes the short story by Edgar Alan Poe, attributing the displacements of the story's letter to the signifier's trajectory, and attributing the letter itself, not its content, to its existence, although not making it explicit in that text , resuming it in 1971, with the letter. In the second text, he deepens the notion of letter, approaching it, metaphorically to littoral, as seen above, in which, in Laurent's words, we would have "water courses as a kind of trait that abolishes imaginary" (2010, p. 74. Free translation). This trait Lacan extracts from the Siberian landscape seen from the plane "is not without reference to Chinese painting (...) like that of a calligraphy, like a pure trait that operates without indicating, without signifying what is there (...)" (Laurent, 2010, p. 75. Free translation).

The author organizes in this text the division of writing alphabetically - western - and ideographically - oriental (2010, p. 63). Thus, in writing, there is a network of signifiers in which what serves to communication is articulated, to which is shared in the Other, which is organized as common meanings - that would be the order of the alphabetical writing - and what is not articulated as meaning, but counts so that all the mentioned articulation may happen - belonging to the order of the ideographic writing, of calligraphy, of the letter. This calligrapher painting, where the goal is not, as in the Renaissance painting, to describe the world, to order internal chaos, but to order by means of a brush stroke, to 
act by tracing. This is where the painter's gesture (...) meets that of the child who launches the fort-da reel (...). It is not just the phonetic opposition o-a, fort-da, but the gesture itself that counts, since it bears the inscription of this trait
(Laurent, 2010, p. 80. Free translation). With this gesture in which "the singular of the hand crushes the universal" (Lacan, 1971, p. 20. Free translation), we can move on to our final articulation proposal.

\section{LACAN WITH PINA BAUSCH}

With these brushstrokes on the letter, the signifier and the signified, we can try to visualize these plans in Pina's pieces' structure, based on the style of her creative process. Let us see again how this process took place, as described by Anne Cattaneo:

Bausch begins to work with her international and multilingual company (her plays use a mixture of French, Spanish, English, German, Portuguese, and other languages) around a piece of music or a text and slowly starts to investigate the emotions, thoughts, long-forgotten memories, and attitudes the members of the company associate with it. (...) At the end of about six weeks, Bausch chooses a hundred or so stories, images, gestures, and sentence fragments from her list (her "catchwords", as Hoghe calls them) and these form the spine of the work. The second half of the rehearsal period is devoted to discovering the form of the piece - how the images should be connected and ordered. Here Bausch may work purely visually - juxtaposing words and gestures, groups of dancers, etc., like a giant jigsaw puzzle to find the structure that supports the evening's theme (Cattaneo, 1984, p. 85 e 86).

These catchwords, an expression used by Raimund Hoghe in his 1982 book, What All is a Tango Good For?, according to Cattaneo, are the result of the reduction operation that Pina was making, as previously mentioned. Reduction of a universe of meanings - feelings, emotions - to fragments and pieces. In the second moment of the creative process, the assembly takes place, the sewing of these pieces. There, then, we have the signifiers of the Other - in their slide of meanings -, the material that Pina decants and the network it articulates, delimited by this material. What most strongly appears, we can see, is the language as material, and the language as meaning. And what does the letter effect produce on the scene? As in calligraphy, it is the gesture that counts. It is a "condansation" (Lacan, 1975-1976, p. 150. Free translation) - borrowing a neologism that Lacan created in his seminar 23 to speak of a dance that would, precisely, condensate something of the real, unlike what is understood as dance in a cultural sense, tributary of the imaginary. "Faire avec" fragments; a handmade and singular sewing that counts on this fraction of the real, hooked by the very imbricated gesture of doing in question.

Take The Rite of Spring reinterpretation, presented by Pina for the first time in 1975. The elements on stage compose a fiction, borrowed from Stravinsky's renowned play, but through the gestures of Pina Bausch. To the story of the young woman who needs to be sacrificed due to the arrival of spring, mud, she adds almost naked bodies and a red cloth. As much as we refer to the original plot, or any other plot that we envision to weave for those movements, what appears is an assembly with mud, nudity and red cloth, whose character of invention is something we cannot get rid of. There is, on the stage, an image that puts on - whether from Stravinsky's music, or whatever - on the side of meaning. There is also signifier's hole, insofar as the markings on the scene equivocate the meaning; the misunderstanding is put. Finally, there is the gesture, the "pure trait", which communicates nothing and, as in calligraphy, takes care of that mud drawing itself, the nakedness and the red cloth, presenting knowledge unknown, nor to be known, but that presents itself. Bauschian gestures make a singularity on the scene real; they write a letter ${ }^{3}$.

3 The research presented in this article is by no means exhausted here. We tried to bring to light some points that we think are fundamental to our attempt to weave the letter with Pina's movements. We feel the notion of meaninglessness, which seems to not only take shape in its montages, but seems to be the privileged material with which to do something in that space that takes us to the coast. The effort to organize, in this work, concepts and ideas that we consider pertinent to the theme, produced a base from which we could start and go deeper in this research. 


\section{REFERENCES}

Arrivé, M. (2001). Linguística e psicanálise. Edusp (Original work published 1986).

Bausch, P. (1975) The rite of spring. Wuppertal.

Bausch, P. (1978) Müller Café. Wuppertal.

Bausch, P. (2000) Dance, senão estamos perdidos. Caderno Mais! Folha de S. Paulo, São Paulo.

Bausch, P. (2007) What moves me. Discurso proferido por ocasião da premiação de Kyoto, 2007. Disponível em: <http:// www.pinabausch.org/en/pina/what-moves-me $>$. Retrived in $15 / 05 / 2017$.

Cattaneo, A. (2013) Pina Bausch: "You can always look at it the other way around". In Climenhaga, R. (org.). The Pina Bausch Sourcebook: the making of tanztheater. New York: Routledge Taylor and Francis Group. (Original work published 1984).

Climenhaga, R. (2013) The Pina Bausch Sourcebook. New York: Routledge Taylor and Francis Group.

Cypriano, F. (2005) Pina Bausch. Cosac Naify.

Freud, S. (2006) “A interpretação dos sonhos", in Edição Standard Brasileira das Obras Psicológicas Completas de Sigmund Freud. Vol. 5. Rio de Janeiro: Imago (Original work published 1900).

Lacan, J. (1998a). O estádio do espelho como formador da função do eu. Em J. Lacan, Escritos (pp. 96-103). Jorge Zahar. (Original work published 1949).

Lacan, J. (1998b) "Função e campo da fala e da linguagem em psicanálise". Em: Lacan, Escritos (pp. 238-324). Rio de Janeiro: Jorge Zahar (Original work published 1953).

Lacan, J. (1998c). A instância da letra no inconsciente. In J. Lacan, Escritos (pp. 496-533). Jorge Zahar. (Original work published 1957).
Lacan, J. (1998d). O seminário sobre "A carta roubada". In J. Lacan, Escritos (V. Ribeiro, trad., pp. 13-68). Jorge Zahar. (Original work published 1955).

Lacan, J. (2008) "O desejo da mãe", in O Seminário, livro 6, o desejo e sua interpretação. Rio de Janeiro: Jorge Zahar (Trabalho original publicado em 1958).

Lacan, J. (2008) O Seminário, livro 6: o desejo e sua interpretação. Jorge Zahar (Trabalho original publicado em 1958-59).

Lacan, J. (1998e). Subversão do sujeito e dialética do desejo no inconsciente freudiano. In J. Lacan, Escritos (pp. 807-842). Jorge Zahar. (Original work published 1960)

Lacan, J. (2005) O Seminário livro 10: a angústia. Rio de Janeiro: Jorge Zahar (Original work published 1962-63.

Lacan, J. (2003). Lituraterra. In J. Lacan (2003). Outros escritos (pp. 15-25). Jorge Zahar. (Original work published 1971).

Lacan, J. (2012). O seminário, livro 19: ou pior. Jorge Zahar . (Original work published 1971-1972)

Lacan, J. (2008). O seminário, livro 20: mais, ainda. Jorge Zahar. (Original work published 1972-73).

Lacan, J. (2007). O seminário, livro 23: o sinthoma. Jorge Zahar (Original work published 1975-1976)

Laurent, É. (2010) A carta roubada e o vôo da letra [The stolen letter and the flight over the letter]. Correio.Revista da Escola Brasileira de Psicanálise, 65. EBP (Original work published 1998).

Leclaire, S. (1977) Psicanalisar. Perspectiva.

Miller, J-A. (2015) $O$ osso de uma análise $+O$ inconsciente e o corpo falante. [The bone of an Analysis] Zahar (Original work published 1998). 